\title{
Membantai Kabau Nan Gadang: the local wisdom of Nagari Alam Pauh Duo
}

\author{
Desmailafrita $^{1}$, Fitri Eriyanti ${ }^{2}$, Erianjoni $^{3}$ \\ 123Universitas Negeri Padang, Padang - Indonesia, (desmailafritayosesri0912@gmail.com)
}

\begin{abstract}
Membantai Kabau Nan Gadang is the traditional herritage from ancestors with a purpose planting patterns simultaneously. In a Minangkabau proverb is said "ka sawah basamosamo, ka ladang badakok-dakok". The history of this traditional ceremony is a form of trustworthiness of the local community which is a part of the local wisdom in farming activity for increasing sufficiency of food through planting patterns simultaneously. The purposes of this research are : background of the traditional ceremony and the implementation process. This research is qualitative research. It was conducted with the ethnography approach. The results of this research: The history of this traditional ceremony was a symbol peace between ancestors in snatching area, and reasons of the society defend: belief of nature, the history of Nagari Alam Pauh Duo, and collective awareness of niniak mamak. The process in two days. The first day is slaughtering buffalo. The second day is eating bajamba surang-surang, watching regional art, agriculture department officer gives instructions and reading amad. The last step is closing by praying together.
\end{abstract}

Key words: the local wisdom, membantai kabau, agriculture.

\section{Introduction}

Minangkabau Culture has been inherited from generation to generation and has been a custom of life of the society. Different regions have different cultures which is known as adat salingka nagari. This shows that Nagari has its own cultural uniqueness affecting local people lives which as a part of Minangkabau culture. Existing culture is preserved and maintain through local wisdom. Local wisdom includes all phrases, languages, behavior patterns and the results of human creation (Daryusti, 2010:1).

According to Suardiman in Harnawati, Abdulkarim et al (2016), local wisdom is closely reated to spriritual or religious behaviors, signs of nature, living/agricultural environment, houses, education, weddings and birth, foods, cycle of human life and human nature, health and natural disaster. One of Minangkabau areas which has local wisdom is Nagari Alam Pauh Duo placed in Pauh Duo subdiatrict, Solok Selatan regency. 
Membantai Kabau Nan Gadang eventin Nagari Alam Pauh Duo is a local wisdom in agriculture. Such local wisdom is not only found in Nagari Alam Pauh Duo but also in other regions such as Sedekah Buka Kebun in South Sumatera, Subak in Bali, Wate Waes in Manggarai, Ritual Pemurnian Desa in Kediri, Muang Jong in Bangka Belitung, Manaie and Seke in North Sulawesi and Kanuri Blang in Aceh (Maifianti, Sarwoprasojdo,dkk, 2014).

Nagari Alam Pauh Duo has tropical climate and is located at $450 \mathrm{M}$ above the sea level. Its rainfall is about $4.287 \mathrm{~mm} /$ year with the total 6 months of rain. Its climate is caused by its far location from Indian Ocean that sends monsoons to Indonesia bringing a lot of water vapor that result in rainy season. According to the climate, the plants and animals existing in Nagari Alam Pauh Duo are tropical plants and animals. For agriculture, rice (paddy) is very suitable to be cultivated in the land of Nagari Alam Pauh Duo because the soil is very fertile. This makes Nagari Alam Pauh Duo one of rice barns in South Solok Regency (Profil Nagari Alam Pauh Duo, 2016: 16)

Membantai Kabau Nan GadangIs a form of culture of the local community adaptation to surroundings in the context of fulfilling needs. Agricultural potential in Nagari Alam Pauh Duo has already been famous with it's rice plant, this is supported by a blessed land and a good source of water. So shat, most of the people in Nagari Alam Pauh Duo are farmers.In ancient times, traditional ceremony of Membantai Kabau Nan Gadang was held before growing season and it was routinely carried out once a year....

Membantai Kabau Nan Gadang is the traditional herritage from ancestors with a purpose planting patterns simultaneously. Planting patterns simultaneously followed by the improvement of construction, irrigation and technology in agriculture sector is government's efforts to increase domestic rice production (Yandri, \& Irawan, 2005: 27). The goal of the Government and this traditional ceremony is having sufficiency of food. In a Minangkabau proverb is said "ka sawah basamo-samo, ka ladang badakok-dakok" " (which means many hands make light work). This similar beliefs were embedded in the of the local people/farmers. So at that time, nagari was safe and prosperous, livestocks bred, padi masak jaguang maupiah (equal to to kill bird with one stone meaning) because all people's foods and needs had been fullfiled.

Traditional ceremony is one of hereditary culture inherited since ancient times. Although the implementation has been changing, the local people still believe, practice and interpret it. Geertz explained that culture is a pattern of meanings which is historically passed and manifested in symbols, or is a inherited concept system expressed in the form of symbols, by which humans communicate, preserve and develop their knowledge about lives and attitudes in life (Geertz, 1995: 5).

Culture is based on interpretation. Through interpretation process, humans control their attitudes and actions. Culture geertz split into two elements that "model of" and "model for". Model of explained that culture as the cognitive system and the system. A model for explain of culture as value system. (Syam Nur,2007:91) . In a meaningful activity that is practiced by a community, the meanings are interpreted as human's activity. The traditional ceremony of Membantai Kabau Nan Gadang is a culture inherited by ancestors which has values and norms that are still believed in the truth and proven to have been performed though its practice and and purposes have changed. Practicing a custom and belief which are acquired by an individual is a legacy that should be practiced and interpreted by the local people.

In fact, it was found that simultaneous planting was difficult to execute and the traditional ceremony practices have changed. The ceremony is not routinely held in Nagari Alam Pauh Duo. The event was last held from 09 $9^{\text {th }}$ until $10^{\text {th }}$ of December 2017, which was previously held in 2015. The traditional ceremony is a hereditary heritage of the ancestors. Although it has changed, the local people still believe, practice and see it as a way to avoid misfortune. In the event, they slaughter a water buffalo followed by big feast in jamba surang-surang (a big tray filled with foods and a group of 
people eat from it) and Doa (praying) as a closing so that God will keep outbreaks and distress such as pests away. So that it can indirectly increase rice roduction.

According to writer's observation, no research has been conducted regarding traditional ceremony of Mambantai Kabau Nan Gadang in Nagari Alam Pauh Duo of Pauh Duo District inSouth Solok Regency. However, there were some studies conducted in other locations which studied other traditional ceremonies that had at least similar purposes. The results were used as reference for current research. The related studies are reviewed as follows:

First; Maifianti, Sarwoprasodjo, et al. (2014) research entitled: "Ritual Communication of Kanuri Blangas A Form of Togetherness of Farmer Community at Samatiga District ofWest Aceh Regency in Aceh Province". This article discussed about the ritual of Kanuri Blang, a tradition of farmer community in Aceh, whose aims were to be thankful and grateful to the grace and sustenance that God has given and to pray to God that this time the plant was also blessed and protected from pests.

Second; Slamet, Ernawati et al. (2015) research entitled: "Lake Space Utilization in the tradition of Sedekah Bumi at Creme Kidul Village of Creme District in Kresik Regency". The conclusion explained that this tradition is an expression of gratitude to the omnipresent God for the abundant harvest. The tradition of Sedekah Bumi was performed under the Lom Tree which is believed by the local people for having a function as pepunden telaga (lord of the lake). The lake held water in the rainy season. Then, the water was used for rice field irrigation, fishponds and daily needs. The event of Sedekah Bumi was attended by local people who brought various foods, side dishes, grilled chickens and fruits.

Third; Middya Botty (2002), whose research title is "Meaning of the ceremony of Kenduri Pusako in Social Interaction of Kerinci society" concluded that: the ceremony of Kenduri Pusako was considered sacred because the tradition had been trusted and mandated from generation to generation. Kenduri Pusako was performed as not to violate the provisions of the ruler of the unseen world fo the sake of ecosystem sustainability. According to People of Tanjung Pauh and Punai Merindu, if the ceremony of Kenduri Pusako was not performed after the harvest, they believe that in the future the crops would not be plentiful or reduced because the ruler (of the unseen world) that ruled the land did not bless them. Even calamity might also happened if their agricultural business (rice) was not concluded by the ceremony of Kenduri Pusako.

Fourth; Windia, Sumiyati, et al. (2015) studied about : "Ritual Aspect of Subak's Irrigation System as A World Cultural Heritage". This journal explained that the people of Bali usually performed a ritual in Subak Temple and in their own rice fields before working on it.

As far as the researcher knew, no research regarding the traditional ceremony of Membantai Kabau Nan Gadang had been conducted before current study. However, mentioned studies above are with the same sense of this study.

Based on the background above, the purpose of this research is to answer the questions below:

1. What is the historical background of the traditional ceremony of Membantai Kabau Nan Gadang so the local people preserve it? 2)

2. How is the process of the traditional ceremony of Membantai Kabau Nan Gadang ?

\section{Method}

This qualitative research used an etnography approach. this research conducted of Nagari Alam Pauh Duo, Pauh Duo subdiatrict Solok Selatan regency. The data was collected through participant observation, unstructured interview, and documentation/literature study. There are 28 informants of the research. The research was conducted from $7^{\text {th }}$ of November- Januari 2018. The data was analysed by using Spradley method.

\section{Result and Discussion}


Background traditional ceremonies Membantai Kabau Nan Gadang so the local people preserve it

As a start of rice planting season in Nagari Alam Pauh Duo was held once a year where the farmers together plants the rice in the fields. This ceremony is held before planting season. It is a hereditary heritage of the ancestors and has been practice until today eventhough it is not a routine like in the past.

The words Membantai Kabau Nan Gadang has their own meaning. Membantai means slaughter, Kabau means water buffalo, Nan Gadang means raised by a deal. Literally, Membantai Kabau Nan Gadang is defined as slaughtering a water buffalo whose price has been agreed together beforehand by all of niniak mamak in Nagari Alam Pauh Duo which amounts to 101 people. The criterion of the buffalo is not determined by the size of body but by its good and non defective physical character eventhough the size is small. Then, the value of the buffalo will be raised by niniak mamak through discussion. So, the definition of Nan Gadang does not refer to the biggest size but it refers to the result of discussion between niniak mamak regarding value or price of the buffalo that are going to buy for the ceremony.

The money for purchasing the buffalo is the dues from family members (children and nephews) of clan living in Nagari Alam Pauh. proverb customary:Mamak dimuko hutan, kemenakan dimuko bayaran. This means the dues for purchasing the buffalo are from the anak kemenakan of niniak maka not from niniak mamak's money.

\section{The History of Membantai Kabau Nan Gadang (slaughtering of a big buffalo)}

The traditional ceremony of Membantai Kabau Nan Gadang is a hereditary heritage of the ancestors of the people of Pauh Duo. However, there is no definite information as to when the ceremony was first performed in Pauh Duo. The result of interview with the historical experts of Nagari Alam Pauh Duo informed that the ceremony is there after the arrival of Inyiak Kurang Aso 60 to Alam Surambi Sungai Pagu. In the past, Nagari Pauh Duo was part of Alam Surambi Sungai Pagu Kingdom which was ruled by Bagindo Sultan Besar Tuanku Rajo Disambah Rajo Alam Surambi Sungai Pagu.

Inyiak kurang Aso 60 was from Pagaruyuang Kingdom who came to Sungai Pagu to create a new territory/Nagari while at that time sungai pagu was inhibited by the natives named Si Tatok Sitaan. According to the story, Si Tatok Sitaan were fought by Inyiak Kurang Aso 60 and driven out to Aceh land preventing them from returning to Sungai Pagu.

After the leaving of Inyiak Kurang Aso 60 and Sitatok Sitaan who fought into the area of Aceh, there came Inyiak Pauh Duo whose names were Inyiak Samiak and Inyiak Jo lelo who came from the border area of Jambi and Palembang. The two Inyiak started to build nagari, mamancang (fix the ground), malatiah (training and intructing), marimbo (woodcutting and hunting), marayo membuek janjang sawah dan banda buatan (making fields and ditches). When Inyiak kurang Aso 60 returned, nagari had been occupied by Inyiak Pauh Duo that the conflict occured between the two clan. Inyiak Pauh Duo lost in numbers compared to Inyiak Kurang Aso 60 followers. So, Inyiak Pauh Duo decided to leave nagari and go to the forest which is later called Rimbo Sianok by the local people where the upstream which, at that time, irrigated the fields is located.

As if not accepting his defeat with Inyiak Kurang Aso 60, whenever Inyiak Kurang Aso 60 grew plants, Inyiak Pauh Duo damaged crops/fields planted by peole of Inyiak Kurang Aso 60 that affected the production. Then, Pagaruyuang Kingdom sent one of the family members, named Dt. Jonan Baso to reconcile Inyiak Pauh Duo and Inyiak Kurang Aso 60 with the provision of Mambantai Kabau Nan Gadang. This traditional ceremony became the symbol of peace between Inyiak Pauh Duo and Inyiak Kurang Aso 60 in creating nagary/territory. As the local saying said "janjang latiah di Pauh Duo, Pujuak Pakai di ampek suku, perahu di Pauh Duo, muatan di Kampek suku". 
Membantai Kabau Nan Gadang was originally the symbol of peace but later inherited to the next generation as a traditional ceremony to welcome rice planting season. so at that time, all farmers simultaneously stepped down to the rice fields in Alam Surambi Sungai Pagu Kingdom including the fields in Nagari Alam Pauh Duo. In custom, the territorial area of Alam Surambi Sungai Pagu is, "from Balun Batu Hilie, ka languang jo Koto Baru, to mudik Pauh Duo Nan Batigo, Batang Marintehmudiak, then to SakoLuhak Nan Tujuah, to Pasisia Banda Sapuluah, kalang huluSalido tumpuan Aie Haji " (Syamsurizaldi \& Irawan, 2002: 29).

Membantai Kabau Nan Gadang is now not similar to the pattern of the ceremony in the past. The farmers do not simultaneously plant the rice in the field. The change follows the demands of times for example high quality seeds with a short planting period and economic demands. The process of the ceremony has also changed. However, the local people still believe that the ceremony will prevent a bad luck. If it is not held, pests, especialy mices, will mustiply and destroy the plants. The reasons peple preserve the tradition are:

1) People belief in nature

Belief system of the society in nature is that if the ceremony is not held the mices will increase and this will affect the rice production. People believe that the tradition is inherited by their previous anchestors and that the tradition contains vows of their anchestors. If it is not held, it will negatively affect the rice production. They believe that this ceremony is a way to ask and plead God to keep epidemic and pests out of their fields.

2) Related to the history of Nagari Pauh Duo

Another reason is the history of the traditional ceremony of Membantai Kabau Nan Gadang which is related to the arrival of Inyiak Pauh Duo in developing nagari/territory. The hisroty of Membantai Kabau Nan Gadang is also related to the history of Alam Surambi Sungai Pagu Kingdom. If the ceremony is erased, the history of Nagari Alam Pauh Duo will be also erased. The history of the ceremony also related to the history Inyiak Kurang Aso 60 in his effort to develop nagari/ territory into a kingdom of Kerajaan Alam Surambi Sungai Pagu whose ruler was Daulat yang Dipertuah Bagindo Sutan Besar Tuangku Rajo Disambah which was located in Pasir Talang.

3) Collective awareness of Niniak Mamak

The traditional ceremony of Membantai Kabau Nan Gadang involves all of niniak mamak in Nagari Alam Pauh Duo. That is why this ceremony also called as alek gadang niniak mamak. The event can be held due to niniak mamak's agreement. If this requirement is not done then there will be disaster. The result of interview with customary experts in Nagari Alam Pauh Duo, the event of Membantai Kabau Nan Gadang will be continously preserved as long as the system of niniak mamak still exists in di Nagari Alam Pauh Duo and the event will be held at least once in \pm 2 years.

\section{The procedures of the event}

The ceremony of Membantai Kabau Nan Gadang in Nagari Alam Pauh Duo was held on The event was last held $09^{\text {th }}$ until $10^{\text {th }}$ of December 2017. Its implementation followed several stages.

a. The preparatory stage

The preparatory stage includes several times deliberation

1) General Meeting

The general meeting stage consists of a number of conference or discussion. General meeting was held on $12^{\text {th }}$ of November 2017 at 09.00 WIB and located at SD 04 Ujung Jalan. The coference was attended by all the members of niniak mamak in Nagari Alam Pauh Duo. The results of discussion at the are:

a. All the members of niniak mamak in Nagari Alam Pauh Duo agreed to hold the traditional ceremony of Membantai Kabau Nan Gadang; 
b. The ceremony was held after the event of Maulid Nabi Muhammad SAW on Saturday and Monday precisely on $09^{\text {th }}$ until $10^{\text {th }}$ of December 2017;

c. The price of the buffalo was \pm 20 million rupiahs (twenty million rupiahs;

d. Each niniak mamak's fee is Rp. 100.000,- (seratus ribu rupiah) and the less amount was covered cash money of Kerapatan Adat nagari (KAN) Pauh Duo.

2) Rapat Muncak (meeting of clan heads)

The preparation stage was followed by Rapat Muncak (meeting of clan heads) which was done $17^{\text {th }}$ of December 2017 at 04.00 WIB and located at the office of Wali Nagari Luak Kapau. The meeting was attended by 8 clan heads and administrators of Kerapatan Adat Nagari (KAN) Pauh Duo. The results of meeting are mentioned as follow:

a. The location of slaughtering on the first day was in Al-ikhlas Mosque Taratak Bukareh which was the location of kapalo banda (a water source for field irrigation in Nagari Alam Pauh Duo);

b. Event mechanism was performed according to the tradition that has been existed for generations. Initially, the administrators of KAN suggested that activity on the first day was done by butcher. However, the clan heads disagreed and decided to follow the same procedures as their anchestors';

c. The decided location of the feast on the second day was in Darussalam Mosque Ujuang Jalan by considering the weather conditions. If it was rainy on that day the agenda could be iside the mosque.

\section{b. Main Event}

The traditional event of Membantai Kabau Nan Gadang was held for 2 days. On the first day, the event was held on $9^{\text {th }}$ of December 2017. The responsibility of buying and choosing the cow was held by clan heads. The criteria of the buffalo such as price and physical characteristics should be consistent with what had been agreed in the clan heads meeting. Kantor Urusan Agama (KUA) is responsible to supervise the slaughtering which was done by paradubalang.

The distribution of the meats was done based on the inherited tradition from their ancestors. Para dubalang got the head part with the exception of the brain (banak kabau) which was given to Dt. Rj.Mulia. the clan heads got the legs. Since there were 8 clan heads, a leg was cut into two so each clan head got a half part of the leg. Each niniak mamak received $1.5 \mathrm{Kg}$ of meats. The meats were then given to their clan and cooked by anak kemenakan. There was no special rule about the dish they should make. The dish was up to the cook. Some of them cooked the meat together while some of them cooked the meal individually in their own house. In addition to the meat dishes, they also cooked other side dishes such as chicken, fish and cake.

On the Second Daythe event was held on $10^{\text {th }}$ of December 2017, a feast was held in Darussalamm Mosque of Ujung Jalan. The location was chosen by following a custom that is in the area of Dt. Bando Satia. The preparation of the location for the second day was mandated to dubalang, including the equipments and the decorations. On this day, peak event was held and was quite festive compared to the first day. The event on the first day was only attended by niniak mamak, dubalang and muncak while on the second day all niniak mamak and their families attended the feast. Every niniak mamak wore special traditional clothes and female anak kemenakan brought jamba which was filled by cooked rice, various side dishes and cakes. This event was also known as eating together from jamba surang-surang (own tray). This event was also attended by Sekda (regional secretary) of South Solok, DPRD (regional people's representative assembly) of South Solok, the Regent of Pauh Duo and agricultural UPTD (regional technical implementation unit) of Pauh Duo. 
In the event Agricultural UPTD of Pauh Duo spoke about plakat turun ke sawah. Plakat turun ke sawah talked about the regulations and rules in agriculture such as irrigation construction, seeding, planting, types of rice seed and harvest time. Traditional agenda was the recitation of Amad which contained prohibitions and taboos during planting season and this Amad was inherited from previous ancestors. The even was closed by do'a (praying) that wished for successful agricultural products especially rice productions. As the Minangkabau saying said, ka sawah basamo-samo, ka ladang badakok-dakok so that their food needs would be fullfiled.

In the ceremony, there is Adam recitation, a written list of prohabition and taboos that has been inherited from generations to generations. It contains the prohabitions and taboos that should be avoided during planting season. The content of Amad is one of a way how local elements try to help the farmers.

1. Karimbo, kayu ndk buliah ditabang, rotan tak buliah dirangguikkan, manau tak boleh dipancuang.- It talks about the probitions of harvesting forest resources such as wood, rattan, and manau;

2. Ka Batang aie, aie tak buliah dikaruah, batu tak buliah dibaliak, ikan tak buliah dicakau. - it talks about the prohibitions in aquatic area such as river. The people are prohibited to make the water cloudy, flip the stones in the river and scoop the fishes;

3. Buah manih, buah masam tak buliah diambiak atau dipanjek mudo - it talks about the prohibitions of harvesting unriped fruits.

Amad indirectly protect rice plants. The sentence Karimbo, kayu ndk buliah ditabang, rotan tak buliah dirangguikkan, manau tak boleh dipancuang indicates the forest as a habitation of mice and birds. If the people kept cut the trees in the forest, it would lead to deforestation which cause to unstable amount of waters that irrigate the fields. Moreover, tree, manau and rattan are the habitation of birds and mice. If they were cut, mice and birds will run toward rice fields and eat the rice.

Ka Batang aie, aie tak buliah dikaruah, batu tak buliah dibaliak, ikan tak buliah dicakau means if the fishes were fished, the water will be dirty. The same thing also goes with the stones. If they were flipped, the water would become cloudy and low in quality. A low quality water tends to contain grubs that would attact the plants.

Buah manih, buah masam tak buliah diambiak atau dipanjek mudo. Sweet and sour fruits are the food of mices and birds. If they were harvested, birds and mice would come to rice fields to find other food resources.

If amad was broken, it would be ka bawah indak baurek, kaateh indak bapucuak, ditangah-tangah digaeiek kumbang, baa karakok tumbuah di baru iduik sagan iduik mati tak namuah dimakan sumpah satieh (this sentence talks about the effect or punishment if the vows (amad) was broken by the people). When rice has been harvested and the field has been dried the prohabitions and taboos can be ended which is also known as mambubuih amad, and arranged by ordinances in legal wisdom as the guidelines, kok mampang jaan sampai ka subarang, kok mandindieng jaan sampai ka langik, kok bubuih jan maruntuah tabiang, kok ungkai jaan mararak bingkai.

Membantai Kabau Nan Gadang eventin Nagari Alam Pauh Duo is a local wisdom in agriculture.

Agricultural potential in Nagari Alam Pauh Duo has already been famous with it's rice plant, this is supported by a blessed land and a good source of water. Traditional ceremonies this is one of community efforts to adapt to environmental niches or nature. The forms of local wisdom suggested by Jim Ife (in ramadhan, 2016: 20-21) includes local knowledge, local values, local skills, local resources, local decision-making mechanism mekanisme and local group solidarity. The tradition of Membantai Kabau Nan Gadang is one of local wisdoms in the form of local knowledge, local values, local resources and group solidarity. 
As one of local knowledges that relates to history, the history of Membantai Kabau Nan Gadang relates to the history of the arrival of Nagari Pauh Duo society's ancestors. Even it relates to the history of the ancestor's arrival in Alam Surambi Sungai Pagu because Nagari Alam Pauh Duo fell into Alam Surambi Sungai Pagu Kingdom Territory. The local values of this tradition were those commonly known by the local people as amad, the cultural values that contained prohibitions and taboos in rice planting season and aimed to protect people's agricultural products. Values are abstract things in society life. They can be observed in society activities.

Local resources related to geographical conditions of Nagari Alam Pauh Duo which had fertile soil and sufficient rainfall. This tradition invited the society to do simultaneously rice planting because they believe it could keep pests away from their fields. Group solidarity could be seen from collective awareness of niniak mamak because the ceremony was alek gadang niniak mamak. In other words, this tradition was the event of niniak mamak since it involved all elements of niniak mamak in Nagari Alam Pauh Duo. This also means that this tradition will never be gone as long as Nagari Pauh Duo still keep the existence of niniak mamak who are the main supporter of the tradition.

Membantai Kabau Nan Gadang is a special custom for the people of Nagari Alam Pauh Duo which is inherited from generation to generation. Glifford Greetz stated that culture is a pattern of meanings which is historically interpreted and inherited (Greertz, 1992: 17). Geertz is focus on cultural concept of cultural values which become the guidance for the society in acting and facing problems. So, the concept of culture is eventually about assessment guidelines of phenomena understood by the actors of culture. In culture, meaning is individual and public at the same time. This means culture has become a pattern of meanings which later belongs to a collective group.

Culture as a pattern of meanings has been historically inherited and manifested in symbols. Culture also becomes a concept system which has been inherited and revealed in the form of symbols by which humans communicate, preserve and develop their knowledge about life and their attitudes in life.This tradition has useful and meaningful values for the society. Those values are used as guidelines by the society to behave, so that the tradition has been preserved until today. The traditional ceremony of Membantai Kabau Nan Gadang is a cultural heritage which is still preserved by the people of Nagari Alam Pauh Duo as their ancestors' valuable and meaningful legacy.

Geertz divided culture into two definition, namely culture as cognitive amd meaning system and culture as value system. Cognitive and meaning system are the representation of model of. Meanwhile, value system is model for (Syam, 2007: 91). This tradition which is practiced by the people of Nagari Alam Pauh Duo is a representation of model of manifested actions taken when about to carry out agricultural activity (stepping down to the rice field). then, meanings and values in the tradition is a representation of model for interpreting, supporting, and taking an action (as action guidelines). This traditional ceremony is not a new thing and a behavior that has been embedded and become a tradition by which the local people define world, express their feelings, giving values and interpret the action taken.

\section{Conclusions}

Based on the research done above then the researcher some attraction conclusion:

1. The background of traditional ceremony of Membantai Kabau NanGadang was a symbol peace between ancestors Pauh Duo and Kurang Aso 60 in snatching area (nagari), and reasons of the society defend the traditional ceremony of Membantai Kabau Nan Gadang: belief of nature, the history of Nagari Alam Pauh Duo, and collective awareness of niniak mamak.

2. The process of traditional ceremony Membantai Kabau Nan Gadang has several steps. First step is preparation for public and leader of etchnig group meeting. Second step is implementation of traditional ceremony Membantai Kabau Nan Gadang in two days. The first day is slaughtering 
buffalo. The second day is eating bajamba surang-surang, watching regional art, plakat turun ka sawah (agriculture department officer gives instructions) and reading amad (prohibitions). The last step is closing by praying together.

\section{References}

Daryusti. (2010). Lingkaran Lokal Genius \& Pemikiran Seni Budaya. Yogyakarta: Cipta Media.

Geertz. Clifford. (1992). Tafsir Kebudayaan. Yogyakarta : Kanisius.

Maifianti, Sarwoprasodjo, et al. (2014). ."Kumunikasi Ritual Kanuri Blang sebagai Bentuk Kebersamaan Masyarakat Tani Kecamatan Samatiga Kabupaten Aceh Barat Provinsi Aceh. Jurnal Komunikasi Pembangunan". Vol. 12, No.2:1-3.

Middya, Botty. (2002). Makna Upacara Kenduri Pusako dalam Interaksi Sosial Masyarakat Kerinci. Tesis tidak diterbitkan. Padang : Pascasarjana UNP Padang.

Romadhan, Afriani. (2016). Kearifan Lokal Masyarakat Desa Hiang Tinggi Dalam Mengelola dan Melestraikan Adat Nenek Limo Hiang Tinggi, Nenek Empat Betung Kuning dan Muara Air Dua. Tesis tidak diterbitkan. Padang: Pascasarjana UNP Padang.

Slamet, Ernawati, et al. (2015) "Pemanfaatan Ruang Telaga Pada Tradisi Sedekah Bumi Desa Cerme Kidul, Kecamatan Cerme, Kabupaten Gresik". Jurnal RUAS. Vol. 13, No. 1:47-48.

Profil Nagari Alam Pauh Duo tahun 2016.

Yandri, \& Irawan . (2005). Pemberdayaan Potensi Daerah Kabupaten Solok Selatan. Padang: VISigraf.

Harmawati, Abdulkarim, et al. (2016). "Nilai Budaya Tradisi Dieng Culture Festival sebagai Kearifan Lokal untuk membangun Karakter Bangsa". Jurnal of Urban Society's Art. Vol. 3, No. 2: 84.

Syamsurizaldi \& Irawan. (2012). Mengenal Struktur Masyarakat Adat Solok Selatan. Lembaga Kajian Sarantau Sasurambi dan Dinas Pendidikan Kabupaten Solok Selatan

Syam, Nur. (2007). Madzhab-madzhab Antropologi. Yogyakarta: LkiS

Windia, Sumiyati, et al. (2015). "Aspek Ritual pada Sistem Irigasi Subak sebagai Warisan Budaya Dunia". Jurnal Kajian Bali. Vol 05, No.1: 30. 